\title{
VERIFICATION OF GOOD PRACTICES IN FOOD ESTABLISHMENTS IN PETROLINA, SEMI-ARID REGION OF PERNAMBUCO, BRAZIL
}

\author{
VERIFICAÇÃO DAS BOAS PRÁTICAS NOS ESTABELECIMENTOS DE ALIMENTOS \\ EM PETROLINA, NA REGIÃO SEMIÁRIDA DE PERNAMBUCO, BRASIL
}

\author{
Washington Luiz Gonçalves de ALMEIDA JÚNIOR ${ }^{1}$; Jane Viana de SOUZA ${ }^{1}$; \\ Naiana Braga FREIRE ${ }^{1}$; Francimaria Batista MIRANDA ${ }^{1}$; Kênia de Fátima CARRIJO²; \\ Francesca Silva DIAS ${ }^{1}$ \\ 1. College of Veterinary Medicine, Federal University of San Francisco Valley, Petrolina, PE, Brazil. francesca.nobre@univasf.edu.br; \\ 2. Faculty of Veterinary Medicine, Federal University of Uberlândia, Uberlândia, MG, Brazil.
}

\begin{abstract}
This study was conducted jointly with the Municipal Sanitary Surveillance Agency of Petrolina, in the period of August-October 2013, to evaluate the hygienic-sanitary conditions of food producing and commercializing establishments in the municipality of Petrolina. A total of 300 food manufacturer/trader establishments were evaluated based on a Good Manufacturing Practices (GMP) checklist. The evaluation was based on 25 items. The data were computed as 0 for nonconformity and 1 for conformity to the GMP checklist. Data from all districts were analyzed by Principal Component Analysis (PCA). Items such as presence of lamp protectors, clean windows and screens, presence of SOP and training programs for handlers, use of aprons, caps, gloves and disposable towels, and performing periodic examinations of the establishments were evaluated. Fourteen evaluation items showed significant differences $(\mathrm{P}<0.05)$ for frequency of conforming and 9 for nonconforming. The PCA identified five city districts (Centro Norte, Areia Branca, Santa Luzia, Rio Corrente and São Gonçalo) in the municipality that used GMP in their establishments. These results highlight the need to redouble efforts in establishments to ensure the safety of products offered.
\end{abstract}

KEYWORDS: Food handlers. Sanitary hygienic conditions. Sanitary surveillance. Public health.

\section{INTRODUCTION}

Foodborne diseases cause high levels of morbidity and mortality in the general population. To reduce the incidence and economic consequences of foodborne diseases, the World Health Organization (WHO) is committed to collaborating with industries, consumers and the governments of its member states to strengthen and better focus the national food safety efforts (WHO, 2013). In Brazil, the official government agency ANVISA (Sanitary Vigilance Agency, Ministry of Health) requires all catering companies to abide by the Good Practices and Standard Operational Procedures (SOP) Guidelines (SACCOL et al., 2013). Moreover, the Brazilian legislation Board Resolution (RDC) n. 275 from October 21, 2002 focuses on the verification of good practice for food services with the aim of ensuring the hygienic and sanitary conditions of prepared food (BRASIL, 2002).

As the incidence of diseases related to food consumption grows every year, it is necessary to intensify the inspection of food processing establishments in order to safeguard public health (GARAYOA et al., 2017; WHO, 2015). Interestingly, the number of meals consumed outside the home increases the emergence of foodborne illness and, consequently, outbreaks of food toxinfections (LYNCH et al., 2013). In Pernambuco state, foodborne illnesses associated with establishments processing commercialized food, mainly food of animal origin, have been reported (DUARTE et al., 2005; MOURA et al., 2007; SIQUEIRA et al., 2010).

The root causes of foodborne illnesses outbreaks were traced back to poor food handling practices, such as cross contamination of raw and cooked products, slow cooling, inadequate refrigeration of foods, poor worker hygiene and lack of knowledge concerning food safety among food handlers (PICHLER et al., 2014).

Important measures for preventing foodborne diseases caused by inappropriate handling include training of handlers about proper techniques, correct personal hygiene, health assessment, implementation of good production practices, in addition to constant supervision (CAMPOS et al., 2009). Therefore, the objective of this study was to evaluate the hygienic-sanitary conditions of food processing/commercializing establishments based on the Good Manufacturing Practices (GMP) checklist of Brazilian legislation in the municipality of Petrolina, semi-arid region of Pernambuco, Brazil. 


\section{MATERIAL AND METHODS}

This study was conducted in the municipality of Petrolina- State of Pernambuco, Brazil, during the period of August-October 2013. The food manufacturer/trader establishments were inspected in 15 city districts (Areia Branca, Centro Norte, Centro Sul, Cohab Massangano, Dom
ALMEIDA JÚNIOR, W. L. G. et al.

Avelar, Gercino Coelho, Jardim Maravilha, João de Deus, José e Maria, Maria Auxiliadora, Núcleo Zona Rural, Rio Corrente, Santa Luzia, São Gonçalo e Vila Eduardo) (Figure 1), with 20 establishments per city district, totaling 300 establishments. The inspections were conducted with the assistance of the Municipal Sanitary Surveillance Agency of Petrolina.

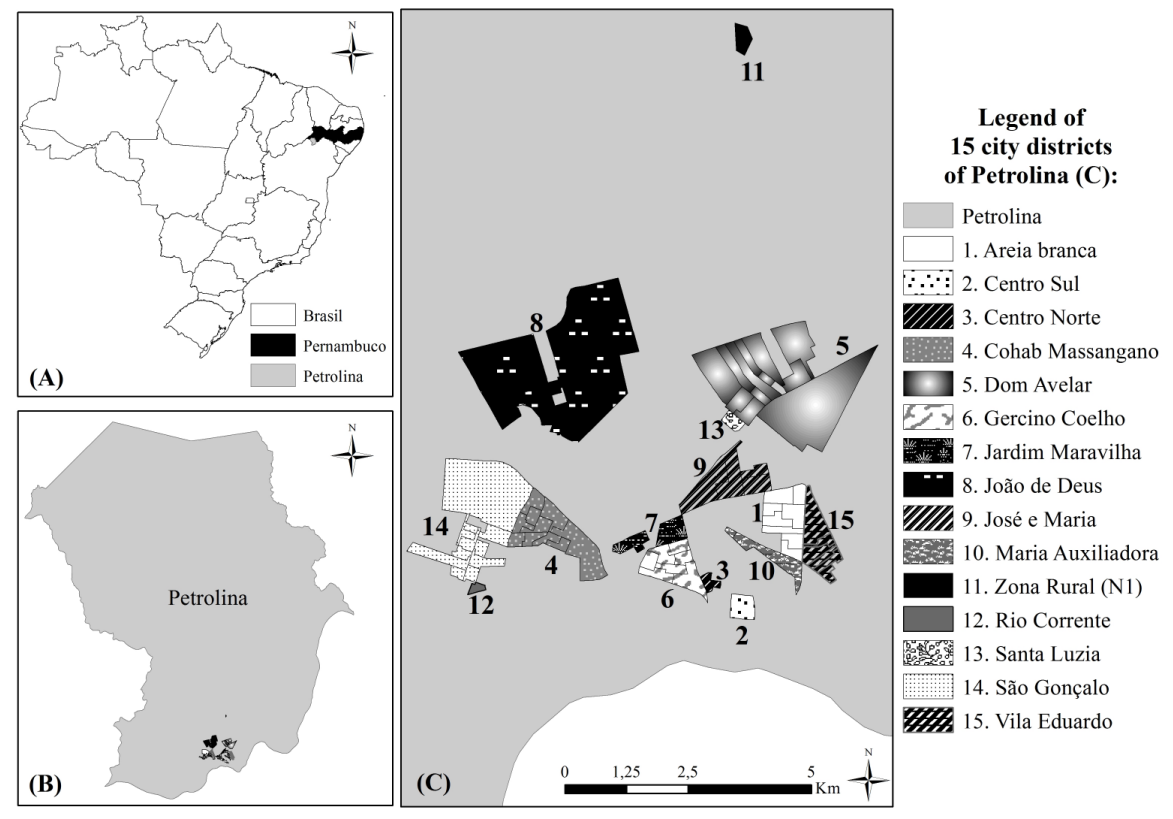

Figure 1. Map of localization: (A) Petrolina, city of Pernambuco State, Northeastern region of Brazil. (B) Municipality of Petrolina and highlight of the city districts visited in this study. (C) The 15 city districts of Petrolina (IBGE, Setor Censitário 2010) where the food manufacturer/trader establishments were inspected.

Each food manufacturer/trader establishment was evaluated based on its observance of Good Manufacturing Practices (GMP). The GMP checklist was based on Resolution (RDC) $\mathrm{n}^{\circ}$. 275/2002 of the National Agency of Sanitary Surveillance (ANVISA) (BRASIL, 2002). The verification was based on 25 items involving the environment /area of handling, processing and commercialization, personal hygiene of food handlers, sanitizing of equipment, utensils, installations and water depletion.

The data were computed as 0 for nonconformity and 1 for conformity to the GMP guidelines. Data were tabulated using Microsoft Office Excel 2010. Descriptive statistics in addition to the Chi-square test were used to determine the significant differences $(\mathrm{P}<0.05)$ between the two categorical variables. The data from all districts were analyzed via Principal Component Analysis (PCA) using the software XLSTAT 7.5.2 (Addinsoft, New York, NY, USA).

\section{RESULTS AND DISCUSSION}

The results show that $86.67 \%(\mathrm{P}<0.05)$ of the establishments did not have Standard Operational Procedures (SOP) (Table 1). The establishment of SOPs is indispensable. According to Brasil (2004), the SOPs contain sequential instructions about the procedures and how often they must be performed. Thus, as the SOPs predict a standardization of a particular activity in sufficient detail and specific guidance, they can prevent the possibility of errors and guarantee the desired quality of the product at every production step. Henriques et al. (2014) showed that the industry demonstrated unsatisfactory implementation of SOPs in terms of both preventive maintenance plans of equipment and hygiene. In another study, 10 out of 17 food handlers would like to see the implementation of documented procedures (e.g., SOP) to ensure effective cleaning of walls, floors, ceilings and equipment (LE et al., 2014). 
The percentage of food handlers with complete and correct use of suitable clothing was very low in the visited establishments selling animal products. Only $42.67 \%$ of the handlers used aprons and disposable caps (Table 1) $(\mathrm{P}<0.05)$. Other studies also showed nonconformance with these criteria (SACCOL et al., 2013; ABD-ELALEEM et al., 2014; CAMPOS et al., 2014; HENRIQUES et al., 2014; SANI AND SIOW, 2014). The purpose of the overall protective clothing is to protect both the food product and the meat handler from cross contamination (ABD-ELALEEM et al., 2014).

In our study, only $19.67 \%$ of the employees used disposable gloves for food handling $(\mathrm{P}<0.05)$ (Table 1). Similar results were reported by Abdelaleem et al. (2014). In a study by Sani and Siow (2014), 63.4\% of the employees did not wear protective gloves to avoid cross-contamination. The use of the glove is fundamental to reduce or prevent bacterial contamination. However, the glove use might be counterproductive because, in accordance to Lynch et al. (2005), often the food handlers wear the same pair of gloves for extended periods. They believe that the simple fact of wearing the glove there is total protection against bacterial contamination. Thus, in agreement with CDC (2010) and FSAI (2011), food handlers must be properly trained to ensure that the gloves are changed frequently and that hands should be washed between glove changes and when gloves are removed. It must also be emphasised that gloves can allow bacteria to build up on the surface of the hands, so hand washing is extremely important when gloves are removed to avoid subsequent contamination of food. The use of gloves does not exempt washing hands before and after contact with any surfaces (BRASIL, 1998).

Table 1. Percentages and $P$-value ${ }^{\mathrm{a}}$ of conformity or nonconformity of GMP checklist in 300 food producing and commercializing establishments in Petrolina, Brazil.

\begin{tabular}{|c|c|c|c|}
\hline Evaluation & $\begin{array}{c}\text { \% Conforming } \\
(\mathrm{n}=300)\end{array}$ & $\begin{array}{c}\text { \% Nonconforming } \\
(\mathrm{n}=300)\end{array}$ & $P$-value \\
\hline Standard Operational Procedures (SOP) to employees & 13.33 & 86.67 & $<0.0001$ \\
\hline Training program for employees & 23 & 77 & $<0.0001$ \\
\hline Employees with uniform (apron) & 42.67 & 57.33 & 0.0003 \\
\hline $\begin{array}{l}\text { Not use of adornment (earring, ring, wristband) by } \\
\text { employees }\end{array}$ & 68 & 32 & $<0.0001$ \\
\hline Use disposable caps by employees & 42.67 & 57.33 & 0.0003 \\
\hline Use of disposable gloves by employees & 19.67 & 80.33 & $<0.0001$ \\
\hline $\begin{array}{l}\text { Absence of skin diseases and wounds in visible regions of } \\
\text { the body handlers }\end{array}$ & 91 & 9 & $<0.0001$ \\
\hline Careful hand wash by handlers & 61 & 39 & $<0.0001$ \\
\hline $\begin{array}{l}\text { Absence of sneeze, spit, cough and manipulation of money } \\
\text { by the handlers. }\end{array}$ & 53 & 47 & 0.1416 \\
\hline Periodic examinations (blood, feces) carried out by handlers & 37.33 & 62.67 & $<0.0001$ \\
\hline Clean environment & 72.67 & 27.33 & $<0.0001$ \\
\hline $\begin{array}{l}\text { Orderly flow of the process of manipulation / } \\
\text { commercialization }\end{array}$ & 77 & 23 & $<0.0001$ \\
\hline Good state of conservation of the floor & 73.33 & 26.67 & $<0.0001$ \\
\hline Good state of conservation of the ceiling & 71.67 & 28.33 & $<0.0001$ \\
\hline Lamps with protection & 26.67 & 73.33 & $<0.0001$ \\
\hline Clean windows and with screens & 12.33 & 87.67 & $<0.0001$ \\
\hline Equipment sanitized before and after use & 66 & 34 & $<0.0001$ \\
\hline Knives different for raw and cooked food & 71.33 & 28.67 & $<0.0001$ \\
\hline Preventive maintenance and calibration of equipment & 64.33 & 35.67 & $<0.0001$ \\
\hline $\begin{array}{l}\text { Refrigeration equipment not turned off the night to energy } \\
\text { saving }\end{array}$ & 84 & 16 & $<0.0001$ \\
\hline Hygiene products identified and stored in a suitable place & 69.67 & 30.33 & $<0.0001$ \\
\hline $\begin{array}{l}\text { Cleaning utensils are kept in good state of preservation } \\
\text { Not use of conventional cloths for cleaning and drying }\end{array}$ & 83.67 & 16.33 & $<0.0001$ \\
\hline hands, utensils and equipment & 27.67 & 72.33 & $<0.0001$ \\
\hline Drains and grates siphoned & 47 & 53 & 0.1416 \\
\hline Integrated vector management for urban pests & 76.33 & 23.67 & $<0.0001$ \\
\hline
\end{tabular}


Only $32 \%$ of the handlers used their adornments, i.e., jewelry (rings, bracelets, earrings) during manipulation of food $(\mathrm{P}<0.05)$ (Table 1$)$. Nonconformance to the adornments use was reported by some authors (CAMPOS et al., 2009; HENRIQUES et al., 2014; OLIVEIRA et al., 2014; SANI AND SIOW, 2014). In another study, it was observed that a vast majority of the handlers knew the risk of food contamination due to the use of adornments. Nevertheless, $74 \%$ of the handlers were wearing adornments during food handling (CUNHA et al., 2014). In this context, our study showed that food handlers have the understanding that all jewelry should be removed, according to the current legislation (BRASIL, 2004).

According to the current legislation (BRASIL, 2004), handlers must wear their hair up, protected by nets, caps or other suitable accessories. Furthermore, handlers must maintain personal hygiene, with uniforms compatible to the activity, conserved and clean, swapped out at least daily, and used exclusively inside the premises of the establishment.

In this study, we observed that $77 \%$ of the handlers did not have access to any training for food handling with proper hygiene $(\mathrm{P}<0.05)$ (Table 1$)$. Similar results were reported by Campos et al. (2009), Aluko et al. (2014) and Sani and Siow (2014). Furthermore, Malhotra et al. (2007) reported that the managers of these establishments did not receive any training involving food. Soares et al. (2013) affirmed that the success in the improvement (enhancement) of the establishment's hygiene is associated to the food handlers' food safety training.

Training programs related to food safety are required, and the establishments should ensure the training and certification of individuals who work in your food service. Training is one of the most effective interventions to ensure quality and food safety (MALHOTRA et al., 2007). Such training should be conducted every six months, with a tolerance of one year (CUNHA et al., 2014).

In this study, a significant number of employees realized that careful hand washing was necessary $(61 \%)(\mathrm{P}<0.05)$ (Table 1$)$. In a study conducted by Sani and Siow (2014) $98.2 \%$ of the employees reported knowing the need to wash hands when handling food. In a study with butchers, $80 \%$ reported that they wash their hands daily at the beginning of work (ABD-ELALEEM et al., 2014). In most cases, hand washing was not performed due to work overload, as food handlers prioritized other activities (CUNHA et al., 2014). Other studies showed a lack of essential care with hand washing when handling food (LUCCA; TORRES, 2006;
CAMPOS et al., 2009; SUN et al., 2012; SACCOL et al., 2013; ALUKO et al., 2014; MARTINS; ROCHA, 2014; OLIVEIRA et al., 2014). Hands are important agents in transmitting microorganisms and intestinal parasites in food (LUCCA; TORRES, 2006). Therefore, Codex Alimentarius (2006) and RDC 216 (BRASIL, 2004) encourage hand washing before food preparation, after any interruption, after touching any contaminated materials, after using toilets, and always when needed.

No sneezing, spitting, or coughing on food is permitted, in addition to no smoking, handling money or performing other acts that may contaminate food (BRASIL, 2002). There was no significant difference in the frequency of these habits in our observed establishments $(\mathrm{P}>0.05)$ (Table 1). During the inspection, handlers performed these inappropriate behaviors during food preparation in $47 \%$ of the establishments. Similar results were observed by Sani and Siow (2014). Another study showed that $70.4 \%$ of the handlers smoked cigarettes and continued smoking in the workplace, and $2.6 \%$ were current smokers in the kitchen or eating areas (MALHOTRA et al., 2007).

In the inspected establishments, there was a significant difference in the frequency of cleaning of equipment before and after food preparation. Approximately $66 \%$ of the establishments were cleaned before and after food preparation. Lucca and Torres (2006), Oliveira et al. (2014) and Martins and Rocha (2014) revealed nonconformance in cleaning and disinfection of equipment and utensils practices. Garayoa et al. (2014) observed that the degree of cleanliness of equipment and utensils was influenced by their place of storage. Utensils that were located below work areas were dirtier than those placed on high shelves or separated from working areas. In addition, the equipment and utensils that were not used often were also found to be dirtier. Second these authors, there is the perception that there is not a concern with the cleanliness of equipment and utensils. Thus, the data found in this present study can be related to the high temperature of the city of Petrolina that contributes to the excessive presence of house flies and mosquitoes. The average annual temperature of the city is $24.8^{\circ} \mathrm{C}$ (CLIMATEDATE.ORG, 2017). House flies densities are highest at mean temperatures of 20 to $25^{\circ} \mathrm{C}$ (WHO, 1991). And of course, dirty equipment and utensils attract these insects. This observation is confirmed by high adhesion of food establishments to integrated vector management for urban pests. 
It was observed that in $71.33 \%$ of the establishments, the employees did not use the same knives for raw and cooked food $(\mathrm{P}<0.05)$. In accordance to Martins and Rocha (2014), there are non-conformities in the handling and storage of raw and cooked foods, favoring cross-contamination. Garayoa et al. (2017) affirmed that the crosscontamination between raw and cooked foods is a recurrent problem and that can contribute to foodborne outbreaks. Thus, the good handling practices are postulated as one of the major preventive actions for pathogen transmission from food handling personnel to the final consumer.

The lack of periodic health examinations (blood, feces) of the handlers $(62.67 \%)$ was significant as per the Chi square test $(\mathrm{P}<0.05)$. The absence of examinations of handlers is common in food establishments. Sun et al. (2012) reported percentages higher than those reported in our study. Similar results were found by Malhotra et al. (2007), Abd-elaleem et al. (2014), Oliveira et al. (2014). Lower percentages were reported by Campos et al. (2009). In a study by Aluko et al. (2014), only $22.5 \%$ of the handlers underwent medical examination in the laboratory to ensure that they were free of foodborne diseases before starting handling of food. Gebreyesus et al. (2014) reported contamination of food handlers by parasites. The authors believe that such results can be related to health certificates that are valid for more than six months, a lack of basic safety requirements and healthy food, and inadequate personal hygiene. Todd (2017) emphasized the importance of asymptomatic carriers as a potential source of foodborne infection. The study exemplified reports of cross-contamination between handlers and food, causing outbreaks of salmonellosis in the Gulf States. In addition, the author highlighted the emergence of resistance in Salmonella and Shigella species. Thus, in accordance to Soares et al. (2013) and Kir et al. (2006), as food handlers are one of the main vehicles for contamination of foodstuffs and may also be asymptomatic carriers of microorganisms that can cause food-borne infections, they should be subjected to detailed examinations by physicians and laboratory investigations prior to commencing services regarding food works.

In $9 \%$ of the inspected establishments, the food handlers had some type of visible lesions on their body (hand dermatitis). There was a significant difference in the frequency of handlers without visible lesions $(\mathrm{P}<0.05)$. Ford (2012) affirmed that occupational hand dermatitis in food handlers and kitchen staff is one of the main causes of ill health.
Skin problems in the industry are related by contact with water, soaps and detergents, with many cases arising from contact with food. In addition, skin lesions it's one of the ways that handlers can spread disease through food (EISERT, 2012). Sani and Siow (2014) reported that $82.8 \%$ of the food handlers admitted to knowing that one should not handle food if they have hand lesions. Bloomfield et al. (2007) reported the violation of law by handlers who continued to work routinely with respiratory or skin infections. According to Health Surveillance System of Brazil, through RDC 216 and the Codex Alimentarius, people affected by or suspected of having any disease that can be transmitted through food, are prohibited from handling food and shall immediately inform the manager.

The frequency of cleaning as well as the proper maintenance of the floor and ceiling was statistically significant, with high values of $72.67 \%$, $73.33 \%$ and $71.67 \%$, respectively. Approximately $53 \%$ of the establishments did not have drains and grates siphoned. The frequency of nonconformance $(\mathrm{P}<0.05)$ for windows and lamps was found in $87.67 \%$ and $73 \%$ of establishments, respectively. Saccol et al. (2013) reported conformity to edification and installations in the studied establishments. However, Oliveira et al. (2014) affirmed that $84 \%$ of the school food service establishments were classified at the highest levels of risk, according to the formula proposed by the authors in the study, where the main problems were related to the lack of screens on windows and inadequate or lack of toilets for food handlers. In the same study, it was found that $86 \%$ of these establishments had inadequately clean floors in the areas of food processing and handling.

As recommended by the RDC 326 (BRASIL, 1997) and RDC 216 (BRASIL, 2004), screens and drains hamper the entry of insects and rodents in the establishments. According to these RDCs, the floors must be resistant to transit, waterproof, washable, non-slip, without cracks and easy to clean and disinfect. The linings and ceilings must have a smooth finish, be waterproof, lightcolored, and in a good state of maintenance and cleanliness. According to current legislation, lamps and luminaires should be clean, explosion protected, in a good state of maintenance and must not alter the sensory characteristics of food.

In this study, it was observed that there was a higher frequency of establishments $(\mathrm{P}<0.05)$ with sufficient space for the flow of the handling process/commercialization, ease of receiving food as well as for production and shipping. Martins and Rocha (2014), also reported the existence of good 
operational flow rationalized in the evaluated feeding units. However, structural problems are quite common, especially in the layout of the installations (DKEKIC et al., 2014). According to Brasil (2002) a lack of sufficient space for the process flow handling/commercialization of food can directly reflect on the sanitary conditions of installations and the preparation, production, handling, packaging and product display, thereby affecting the quality and safety of food.

There was a higher frequency of preventive maintenance and calibration of equipment $(\mathrm{P}<0.05)$, approximately $64.33 \%$ of the establishments performed this action. The equipment must have a smooth surface, be easy to clean and disinfect, with light paint, without grease drip, ice accumulation or constant maintenance (BRASIL, 2002).

Significant difference was found in the practice of unplugging the refrigerator at night. With the aim of conserving energy, this habit was reported by handlers in only $16 \%$ of the establishments, that is, a total of $84 \%$ of establishments did not turn off the equipment at night. The refrigeration equipments were not turned off the night to energy saving. In this study, it was perceived the care of establishments in the maintenance of the temperature for refrigerated foods (presence of thermometer in the refrigerators). It is certain that this precaution occurs due to the high temperatures in the municipality, as mentioned previously. Other studies showed nonconformance with the daily control of temperature suitable for food storage (CUNHA et al., 2014; HENRIQUES et al., 2014; MARTINS AND ROCHA, 2014; OLIVEIRA et al., 2014).

It was observed statistically significant differences for the storage and correct identification of hygiene products $(69.67 \%)$, conditioning of the same in good condition (83.67\%) and the use of conventional cloths for cleaning $(72.33 \%)$. Abdelaleem et al. (2014) showed that $37.5 \%$ of the handlers used disposable paper towels for drying hands, and $32.5 \%$ of the handlers dry their hands with a cloth. The use of cloths to dry surfaces of food contact after routine hygienic procedures were also reported by Campos et al. (2009) and Henriques et al. (2014). Furthermore, Bartz et al. (2010) affirmed that when rubbed on surfaces, contaminated cloths invariably transferred microorganisms to surfaces or the hands of food handlers, increasing the risk to foodborne infections.

Integrated pest control is a common practice as observed in this study. Approximately $76.33 \%$ of the establishments performed integrated vector management for urban pests $(\mathrm{P}<0.05)$. As previously mentioned, the establishments really have the concern in the control of pests, mainly of house flies, that has its population increased due to the climate of the city of Petrolina. According to Saccol et al. (2013), this high level of compliance to the requirements for vector control and urban pests is extremely important, as the high incidence of contamination of food by these agents is well known. Pests are implicated in the dissemination of bacterial pathogens on food products. Niyonzima et al. (2017) reported that the absence of pest control measures in the food establishments (Kigali, Rwanda) were found to be associated with an increasing risk of Salmonella contamination in meat-based food.

To discriminate the 15 city districts included in this study according to the overall characteristics of their establishments, PCA was conducted based on Good Manufacturing Practices (Figure 2). The first seven components explained $70.18 \%$ of the total variance; among them, PC1 and PC2 explained $27.87 \%$ and $14.43 \%$ of the total variance, respectively. GMP was markedly separated in the plane of the biplot. On the upper right quadrant of the plane, the establishments from the city districts Centro Norte and Areia Branca could be differentiated as establishments with clean environments, clean windows and with screens, lamps with protection, good state of maintenance of the ceiling, drains and grates siphoned, orderly flow, training program, use of uniform by employees, absence of skin diseases and wounds in body of handlers, cross contamination (knives different for raw and cooked food) and hygiene products identified and stored. The establishments of the city district Santa Luzia could be differentiated by cleaning utensils, good state of conservation of the floor, SOP to employees and absence of sneeze, spit, cough and manipulation of money by the handlers.

On the upper left quadrant of the plane (Figure 2), the establishments from city districts of Rio Corrente and São Gonçalo are characterized by periodic examinations, careful hand washing and use of disposable caps and gloves by handlers, not use of cloths and adornment, equipment sanitization and maintenance, refrigeration equipment not turned off and integrated vector management. For the city districts of João de Deus, Cohab Massangano and Zona Rural, there was no differentiation in terms of GMP in their establishments. 


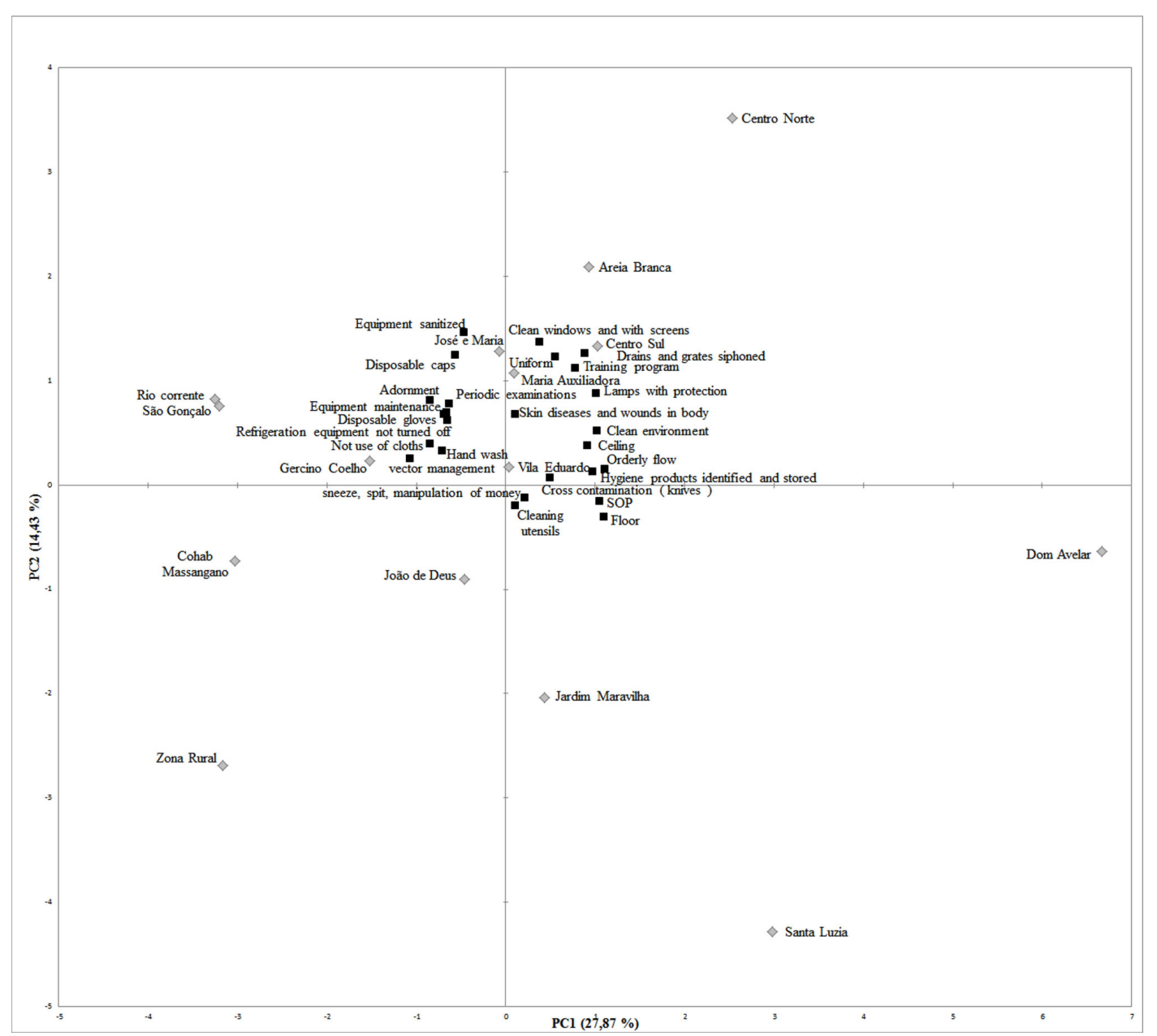

Figure 2. Principal component analysis (PCA) based in the evaluation of establishments data of the 15 city districts of Petrolina - Brazil. The first seven components explained 70.18\% of the total variance; among them, PC1 and PC2 explained $27.87 \%$ and $14.43 \%$ of the total variance, respectively.

\section{CONCLUSIONS}

The results showed overall good adherence to Good Practices. Fourteen items of evaluation presented frequency of conforming. However, nine items were nonconforming and included protection of lamps, clean windows and screens, presence of SOP, training programs for handlers as well as use of apron, caps, gloves and towels disposables, and performing periodic examinations. These items were levied from establishments.

Five city districts (Centro Norte, Areia Branca, Santa Luzia, Rio Corrente and São Gonçalo) were highlighted in the municipality as being GMP compliant. The absence of GMP in manufacturers/traders of food establishments results in serious public health implications. Therefore, mandatory and regular certifications related to food safety should be carried out in all handlers and managers of food establishments, with the aim of ensuring innocuous products and reducing the risk of foodborne illnesses.

\section{ACKNOWLEDGEMENTS}

The authors wish to acknowledge the Municipal Sanitary Surveillance Agency of Petrolina, (Coordinator in the period this study: Jarbas Costa de Oliveira), UNIVASF (Universidade Federal do Vale do São Francisco) and Ministério da Saúde (Pró-Saúde / PET-Saúde) for scholarship and financial support.

RESUMO: Este estudo foi realizado em conjunto com a Agência Municipal de Vigilância Sanitária de Petrolina, no período de agosto a outubro de 2013, para avaliar as condições higiênico-sanitárias de produção e comercialização de alimentos nos estabelecimentos municipais de Petrolina. Um total de 300 estabelecimentos fabricante/comerciante de alimentos foi avaliado com base em uma lista de verificação de Boas Práticas de Fabricação (BPF). A avaliação foi baseada em 25 itens. Os dados foram computados como 0 para a não-conformidade e 1 para a 
conformidade segundo a lista de verificação. As respostas para as observações foram obtidas por Análise de Componentes Principais (ACP). Itens como protetores de lâmpadas, limpeza das janelas e telas, presença de programas de higiene operacional, curso de formação para manipuladores, o uso de aventais, bonés, luvas e toalhas descartáveis e realização de exames médicos periódicos dos manipuladores foram avaliados. Quatorze itens de avaliação mostraram diferenças significativas para frequência de conformidade e 9 para não-conformidade. A ACP identificou cinco regiões da cidade (Centro Norte, Areia Branca, Santa Luzia, Rio Corrente e São Gonçalo) no município que utilizam BPF em seus estabelecimentos. Estes resultados destacam a necessidade de redobrar os esforços nos estabelecimentos para garantir a inocuidade dos produtos oferecidos.

PALAVRAS-CHAVE: Manipuladores de alimentos. Condições de higiene sanitária. Vigilância sanitária. Saúde pública.

\section{REFERENCES}

ABD-ELALEEM, R.; BAKR, W. M. K.; HAZZAH, W. A.; NASRELDIN, O. Assessment of the personal hygiene and the bacteriological quality of butchers' hands in some abattoirs in Alexandria, Egypt. Food Control, Oxford, v. 41, p. 147-150, 2014. https://doi.org/10.1016/j.foodcont.2014.01.016

ALUKO, O. O.; OJEREMI, T. T.; OLALEKE, D. A.; AJIDAGBA, E. B. Evaluation of food safety and sanitary practices among food vendors at car parks in Ile Ife, southwestern Nigeria. Food Control, Oxford, v. 40, p. 165-171, 2014. https://doi.org/10.1016/j.foodcont.2013.11.049

BARTZ, S.; RITTER, A. C.; TONDO, E. C. Evaluation of bacterial multiplication in cleaning cloths containing different quantities of organic matter. Journal of Infection in Developing Countries, Sassari, v. 4, n. 9, p. 566-571, 2010.

BLOOMFIELD, S. F.; COOKSON, B.; FALKINER, F.; GRIFFITH, C.; CLEARY, V. Methicillin-resistant Staphylococcus aureus, Clostridium difficile, and extended-spectrum beta-lactamase producing Escherichia coli in the community: assessing the problem and controlling the spread. American Journal of Infection Control, New York, v. 35, n. 2, p. 86-88, 2007. https://doi.org/10.1016/j.ajic.2006.10.003

BRASIL. Ministério da Saúde. Agência Nacional de Vigilância Sanitária. Portaria no 326, de 30 de julho de 1997. Aprova o regulamento técnico sobre condições higiênico-sanitárias e de boas práticas de fabricação para estabelecimentos produtores/industrializadores de alimentos. Diário Oficial da União, 01 de agosto de 1997.

BRASIL. Ministério da Saúde. Agência Nacional de Vigilância Sanitária. Portaria n. ${ }^{\circ}$ 2.616, de 12 de maio de 1998. Diretrizes e Normas para a Prevenção e o Controle das Infecções Hospitalares. Diário Oficial da União, 13 de maio de 1998.

BRASIL. Ministério da Saúde. Agência Nacional de Vigilância Sanitária. Resolução RDC no 275, de 21 de outubro de 2002. Dispõe sobre o regulamento técnico de procedimentos operacionais padronizados aplicados aos estabelecimentos produtores/industrializadores de alimentos e a lista de verificação das boas práticas de fabricação em estabelecimentos produtores/industrializadores de alimentos. Diário Oficial da União, 23 de outubro de 2002.

BRASIL. Ministério da Saúde. Agência Nacional de Vigilância Sanitária. Resolução n. o 216, de 15 de setembro de 2004. Dispõe sobre regulamento técnico de boas práticas para serviço de alimentação. Diário Oficial da União, 16 de setembro 2004.

CDC. Centers for Disease Control and Prevention. OPRP-Handwashing guidelines. Atlanta: Georgia, USA: CDC, 2010. 
CAMPOS, A. K. C.; CARDONHA, M. A. S.; PINHEIRO, L. B. G.; FERREIRA, N. R.; AZEVEDO, P. R. M.; STAMFORD, T. L. M. Assessment of personal hygiene and practices of food handlers in municipal public schools of Natal, Brazil. Food Control, Oxford, v. 20, n. 9, p. 807-810, 2009.

https://doi.org/10.1016/j.foodcont.2008.10.010

CLIMA-DATE.ORG. Dados climáticos para cidades mundiais Clima: Petrolina. América do Sul, Brasil, Pernambuco, Petrolina. 2017. [Accessed 2017 April 14]. Available in: https://pt.climatedata.org/location/31938/

CODEX ALIMENTARIUS. Organização Pan-Americana da Saúde/Organização Mundial da Saúde. Higiene dos alimentos - textos básicos. Agência Nacional de Vigilância Sanitária. Food and Agriculture Organization of the United Nations - FAO; 2006 [accessed 2015 Aug 04] Available in: <http://www.anvisa.gov.br/d ivulga/ public/alimentos/codex_alimentarius.pdf>.

CUNHA, D. T.; STEDEFELDT, E.; ROSSO, V. V. The role of theoretical food safety training on Brazilian food handlers' knowledge, attitude and practice. Food Control, Oxford, v. 43, p. 167-174, 2014. https://doi.org/10.1016/j.foodcont.2014.03.012

DKEKIC, I.; SMIGIC, N.; KALOGIANNI, E. P.; ROCHA, A.; ZAMIOUDI, L.; PACHECO, R. Food hygiene practices in different food establishments. Food Control, Oxford, v. 39, p. 34-40, 2014. https://doi.org/10.1016/j.foodcont.2013.10.035

DUARTE, D. A. M.; SCHUCH, D. M. T; SANTOS, S. B.; RIBEIRO, A. R.; VASCONCELOS, A. M. M.; SILVA, J. V. D.; MOTA, R. A. Pesquisa de Listeria monocytogenes e microrganismos indicadores higiênicosanitários em queijo de coalho produzido e comercializado no estado de Pernambuco. Arquivo Instituto Biológico, São Paulo, v. 72, p. 297-302, 2005.

EISERT, J. The health of the public is in your hands, a food handler's guide to food safety. In: University of California Environment, Health \& Safety Food Safety Division, 2012. . [Accessed 2017 April 14]. Available in: <http://www-ehs.ucsd.edu/food/FoodHandlersGuideToFoodSafety.pdf>.

FORD, S. Skin problems in food handlers and the catering industry. DermNet New Zealand, New Zealand, 2012. [Accessed 2017 April 14]. Available in: <http://www.dermnetnz.org/topics/skin-problems-in-foodhandlers-and-the-catering-industry/>.

FSAI. Food Safety Authority of Ireland. Scientific Recommendations for Healthy Eating Guidelines in Ireland. Dublin, Food Safety Authority of Ireland (www.fsai.ie), 2011.

GARAYOA, R.; DÍEZ-LETURIA, M.; BES-RASTROLLO, M.; GARCÍA-JALÓN, I.; VITAS, A. I. Catering services and HACCP: Temperature assessment and surface hygiene control before and after audits and a specific training session. Food Control, Oxford, v. 43, p. 193-198, 2014.

https://doi.org/10.1016/j.foodcont.2014.03.015

GARAYOA, R.; CARLOS ABUNDANCIA, C.; DÍEZ-LETURIA, M.; VITA, A. I. Essential tools for food safety surveillance in catering services: On-site inspections and control of high risk cross-contamination surfaces. Food Control, Oxford, v. 75, p. 48-54, 2017. https://doi.org/10.1016/j.foodcont.2016.12.032

GEBREYESUS, A.; ADANE, K.; NEGASH, L.; ASMELASH, T.; BELAY. S.; ALEMU, M.; SARAVANAN, M. Prevalence of Salmonella typhi and intestinal parasites among food handlers in Mekelle University student cafeteria, Mekelle, Ethiopia. Food Control, Oxford, v. 44, p. 45-48, 2014.

https://doi.org/10.1016/j.foodcont.2014.03.040

HENRIQUES, A. R.; GAMA, L. T.; FRAQUEZA, M. J. Assessing Listeria monocytogenes presence in Portuguese ready-to-eat meat processing industries based on hygienic and safety audit. Food Research International, Toronto, v. 63, p. 81-88, 2014. https://doi.org/10.1016/j.foodres.2014.03.035 
IBGE. Instituto Brasileiro de Geografia e Estatística. Bases cartográficas - malhas digitais: municipal e setor censitário. 2010. [Accessed 2017 April 14]. Available in: http://mapas.ibge.gov.br/bases-e-referenciais/basescartograficas/malhas digitais.html.

KIR, T.; UCAR, M.; GOCGELDI, E.; KILIC, S.; AZAL, O. Evaluation of initial and periodic examinations of food handlers in military facilities. Food Control, Oxford, v. 17, p. 165-170, 2006.

https://doi.org/10.1016/j.foodcont.2004.09.016

LE, S.; BAZGER, W.; HILL, A. R.; WILCOCK, A. Awareness and perceptions of food safety of artisan cheese makers in Southwestern Ontario: A qualitative study. Food Control, Oxford, v. 41, p. 158-167, 2014. https://doi.org/10.1016/j.foodcont.2014.01.007

LUCCA, A.; TORRES, E. A. F. S. Street-food: The hygiene conditions of hot-dogs sold in São Paulo, Brazil. Food Control, Oxford, v. 17, n. 4, p. 312-316, 2006. https://doi.org/10.1016/j.foodcont.2004.11.005

LYNCH, R. A.; PHILLIPS, M. L.; ELLEDGE, B. L.; HANUMANTHAIAH, S.; BOATRIGHT, D. T. A preliminary evaluation of the effect of glove use by food handlers in fast food restaurants. Journal of Food Protection, Des Moines, v. 68, n.1, p. 187-190, 2005. https://doi.org/10.4315/0362-028X-68.1.187

LYNCH, R. A.; ELLEDGE, B. L.; GRIFFITH, C. C.; BOATRIGHT, D. T. A comparison of food safety knowledge among restaurant managers, by source of training and experience, in Oklahoma County. Journal of Environmental Health, London, v. 66, p. 9-14, 2013.

MALHOTRA, R.; LAL, P.; PRAKASH, S. K.; KISHORE, J. Profile of food handlers working in food service establishments located within the premises of a medical college in Delhi, India. Public Health, London, v. 121, n. 6, p. 455-461, 2007. https://doi.org/10.1016/j.puhe.2006.08.002

MARTINS, M. L.; ROCHA, A. Evaluation of prerequisite programs implementation at schools food service. Food Control, Oxford, v. 39, p. 30-33, 2014. https://doi.org/10.1016/j.foodcont.2013.10.040

MOURA, A. P. B. L.; PINHEIRO JUNIOR, J. W.; OLIVEIRA, R. B. A.; DUARTE, D. A. M.; RIBEIRO, A. R.; REIS, E. M. F. Pesquisa de Coliformes Termotolerantes, Totais e Salmonella spp. em carnes caprinas comercializadas na cidade do Recife, Pernambuco. Arquivo Instituto Biológico, São Paulo, v. 74, n. 4, p. 293 299, 2007.

NIYONZIMA, E.; ONGOL, M. P.; BROSTAUX, Y.; KOULAGENKO, N. K.; DAUBE, G.; KIMONYO, A.; SINDIC, M. Consumption patterns, bacteriological quality and risk factors for Salmonella contamination in meat-based meals consumed outside the home in Kigali, Rwanda. Food Control, Oxford, v. 73, p. 546-554, 2017. https://doi.org/10.1016/j.foodcont.2016.09.004

OLIVEIRA, A. B. A.; CUNHA, D. T.; STEDEFELT, E.; CAPALONGA, R.; TONDO, E. C.; CARDOSO, M. R. I. Hygiene and good practices in school meal services: Organic matter on surfaces, microorganisms and health risks. Food Control, Oxford, v. 40, p. 120-12, 2014. https://doi.org/10.1016/j.foodcont.2013.11.036

PICHLER, J.; ZIEGLER, J.; ALDRIAN, U. Evaluating levels of knowledge on food safety among food handlers from restaurants and various catering businesses in Vienna, Austria 2011/2012. Food Control, Oxford, v. 35, n. 1, p. 33-40, 2014. https://doi.org/10.1016/j.foodcont.2013.06.034

SACCOL, A. L. F.; SERAFIM, A. L.; HECKTHEUER, L. H. R.; MEDEIROS, L. B.; SPINELLI, M. G. N.; ABREU, E. S.; CHAUD, D. M. A. Hygiene and sanitary conditions in self-service restaurants in São Paulo, Brazil. Food Control, Oxford, v. 33, n. 1, p. 301-305, 2013.

https://doi.org/10.1016/j.foodcont.2013.02.030 
SANI, N. A.; SIOW, O. N. Knowledge, attitudes and practices of food handlers on food safety in food service operations at the Universiti Kebangsaan Malaysia. Food Control, Oxford, v. 37, p. 210-217, 2014. https://doi.org/10.1016/j.foodcont.2013.09.036

SIQUEIRA, L. P.; SHINOHARA, N. K. S.; DE LIMA, R. M. T.; PAIVA, J. E.; LIMA FILHO, J. L.; CARVALHO, I. T. Microbiological evaluation of drinking water used in feeding units. Ciência e Saúde Coletiva, Manguinhos, v. 15, n. 1, p. 63-66, 2010.

SOARES, K.; GARCÍA-DÍEZ, J.; ESTEVES, A.; OLIVEIRA, I.; SARAIVA, C. Evaluation of food safety training on hygienic conditions in food establishments. Food Control, Oxford, v. 34, p. 613-618, 2013. https://doi.org/10.1016/j.foodcont.2013.06.006

SUN, Y. M.; WANG, S. T.; HUANG, K. W. Hygiene knowledge and practices of night market food vendors in Tainan City, Taiwan. Food Control, Oxford, v. 23, n. 1, p. 159-164, 2012.

https://doi.org/10.1016/j.foodcont.2011.07.003

TODD, E. C. D. Foodborne disease and food control in the Gulf States. Food Control, Oxford, v. 73, p. 341366, 2017. https://doi.org/10.1016/j.foodcont.2016.08.024

WHO. World Health Organization. Houseflies. Carriers of diarrhoeal diseases and skin and eye infections. Chapter 6. In: The housefly. Training and information guide (intermediate level). Geneva: WHO 1991. [Accessed 2017 April 14]. Available in:

<http://www.who.int/water_sanitation_health/resources/vector302to323.pdf>

WHO. World Health Organization. Assuring food safety and quality: guidelines for strengthening national food control systems. Geneva: WHO 2013. [Accessed 2017 April 14]. Available in:

$<$ http://www.wpro.who.int/foodsafety/documents/ docs/Englis h_G uidelines_Food_control.pdf $>$.

WHO. World Health Organization. Initiative to estimate the global burden of foodborne diseases:

Information and publications. Geneva: WHO 2015. [Accessed 2017 April 14]. Available in:

http://www.who.int/foodsafety/ publications/foodborne_disease /fergreport/en/ 